\title{
Bioenergy recovery from olive mill effluent in a hybrid reactor
}

\author{
M.R. Gonçalves ${ }^{a, b, *}$, P. Freitas ${ }^{a}$, I.P. Marques ${ }^{a}$ \\ a Bioenergy Unit, National Laboratory of Energy and Geology, I.P. (LNEG), 1649-038 Lisbon, Portugal \\ ${ }^{b}$ Institute for Biotechnology and Bioengineering (IBB), University of Minho, 4710-057 Braga, Portugal
}

\section{A R T I C L E I N F O}

Article history:

Received 30 January 2011

Received in revised form

7 October 2011

Accepted 6 January 2012

Available online 30 January 2012

Keywords:

Biogas

Olive oil mill effluent

Hybrid digester

Phenolic compounds

Anaerobic digestion

Piggery effluent

\begin{abstract}
A B S T R A C T
An anaerobic hybrid reactor was tested in the treatment of raw olive mill effluent (OME) without water dilution, chemical correction and any pretreatment. A feeding strategy was applied by increasing progressively the OME volume fraction from $8 \%$ to $83 \%$ in the feed mixture combined with an OME complementary substrate (piggery effluent).

A biogas production of $3.16 \mathrm{~m}^{3} \mathrm{~m}^{-3} \mathrm{~d}^{-1}$ was achieved at an organic loading rate of COD at $7.1 \mathrm{~kg} \mathrm{~m}^{-3} \mathrm{~d}^{-1}$, when the highest fraction of OME was added to the influent (volume fraction of $83 \%$; COD concentration fraction of about $94 \%$ ). At these conditions, the degradation of olive mill effluent occurred without any inhibition. The reactor was capable to digest an acid influent $(\mathrm{pH}=4.7)$, revealing a high buffering capacity. The increase of influent phenols concentration from $0.87 \mathrm{~kg} \mathrm{~m}^{-3}$ to $2.31 \mathrm{~kg} \mathrm{~m}^{-3}$ did not influence the reactor removal capacity (phenolic fraction removal from $51 \%$ to $61 \%$ ). Biomass acclimation to OME was accomplished by using a feeding strategy based on effluents complementarity. Furthermore, it was demonstrated that the hybrid digester was able to recover after an accidental overload, and the packing material on the top of the unit prevented excessive loss of biomass. Comparatively to the classic configuration digesters, the hybrid digester is an effective alternative to maximize bioenergy recovery from OME.
\end{abstract}

(c) 2012 Elsevier Ltd. All rights reserved.

\section{Introduction}

Olive mill effluent (OME) or the so-called "black water" is a byproduct from olive oil production. The utilization of this residual fraction as a source of energy, nutrients and irrigation water [1] emerges as an attractive solution for OME management.

The high theoretical energetic potential of this effluent is ascribed to the organic load, particularly to the oil content. Biogas production from complex oily wastewaters can be very profitable if operation problems are overtaken. Olive mill effluent toxicity toward microorganisms has been linked to lipidic and phenolic compounds [2-5]. Several authors proposed different treatments before OME biodegradation to remove and/or degrade the OME toxic compounds [6-8]. However, the organic fraction is reduced by most of the pretreatments and consequently bioenergy recovery decreases. The addition of water and chemicals has been widely applied to enhance OME biodegradation (Table 1) [6,8-12].

Co-digestion of OME with other agro-industrial by-products has been recently reported [13-15]. However, in a continuous operation, the highest OME volume fraction applied was $50 \%$ and chemicals were needed to correct the $\mathrm{pH}$. Alternatively, the addition of a complementary wastewater stream to the olive mill effluent can be advantageously applied as it decreases the toxic compounds concentration and also provides the required $\mathrm{pH}$, alkalinity and nutrients

\footnotetext{
* Corresponding author. Bioenergy Unit, National Laboratory of Energy and Geology, I.P. (LNEG), 1649-038 Lisbon, Portugal. Tel.: +351 210924600; fax: +351 217127195.

E-mail address: marta.goncalves@lneg.pt (M.R. Gonçalves). 


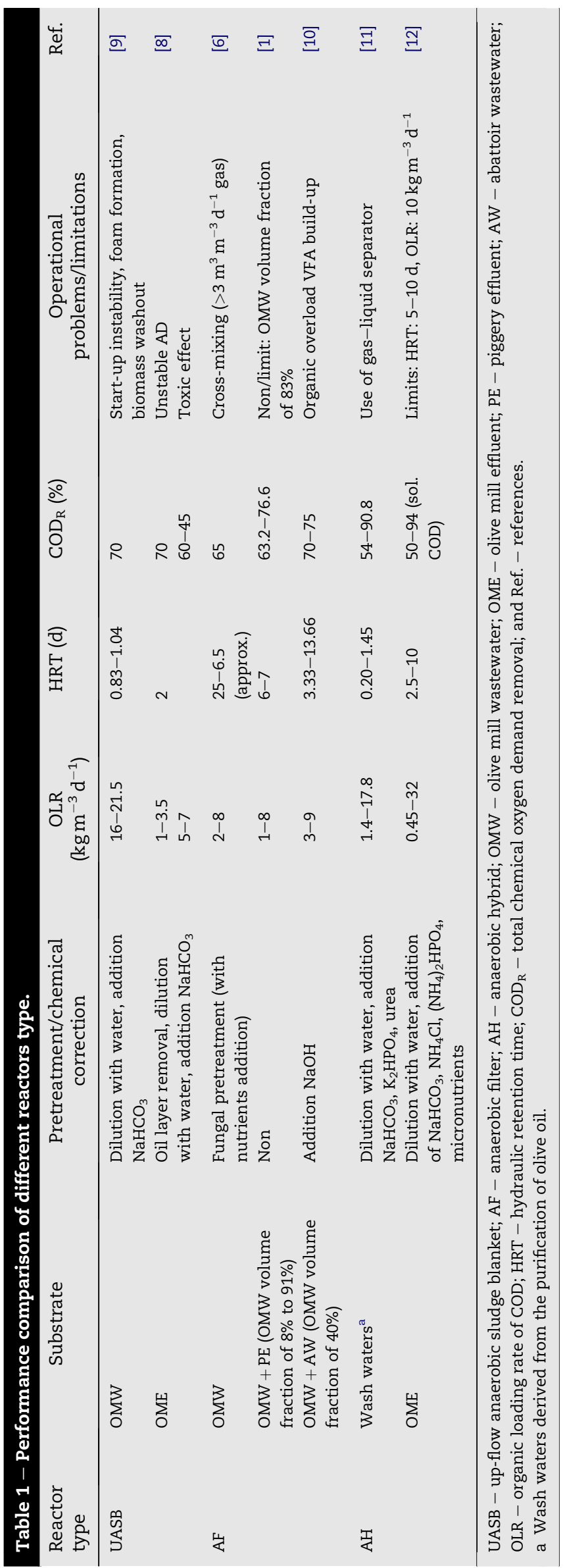

levels necessary for a successful anaerobic digestion. Consequently, higher proportions of OME can be treated $[1,16]$.

The reactor design is another important factor to achieve a good performance and an economic process. Different anaerobic reactor types have been investigated for the treatment of this effluent (Table 1). Up-flow Anaerobic Sludge Blanket (UASB) shows a tendency to wash the biomass from the system under an overload or when concentrated effluents are used $[9,17]$. Anaerobic Filter (AF) is favored for the treatment of OME since it requires a shorter start-up time, and resists to high COD loadings and to high temporary overloads $[18,19]$. Another up-flow packed bed digester is the Anaerobic Hybrid (AH) that gathers several positive aspects of both systems: tolerance to high loading rates and minimization of suspended solids washout which consequently enhances the reactor efficiency and provides better effluent quality [20,21].

This work intends to investigate low-cost alternatives to maximize the energy recovery from OME, regarding mainly the feeding approach and the reactor design. The main objectives were to test and evaluate the performance of a hybrid reactor using (a) a complementary effluent stream in the feed mixture to avoid the use of chemicals and dilutions with water and (b) a packed bed length of only $1 / 3$ of the digester height.

The complementary effluent was not only used to achieve process stability concerning the energetic valorization of both effluents but also to adapt the reactor to OME or to a great portion of it. The importance of using alternatively the hybrid reactor type and the feeding strategy was discussed regarding an anaerobic digestion plant applied to the energetic valorization of OME.

\section{Materials and methods}

\subsection{Experimental set-up}

The anaerobic digestion experiments were performed in an up-flow anaerobic hybrid digester. The unit (Fig. 1) was built out of polyvinyl chloride (PVC) pipe with a total volume of about $2 \mathrm{dm}^{3}$. A packed bed, selected in previous studies [1], was used to fill only $1 / 3$ of reactor's height. No device separator of solid/liquid/gas was installed and no substrate recycle was provided. It was semi-continuously fed by a time controlled peristaltic pump and maintained at $37 \pm 1{ }^{\circ} \mathrm{C}$ using a water jacket. The feed tank temperature was kept at about $4{ }^{\circ} \mathrm{C}$. The gas production was measured by a wet gas meter and corrected to standard conditions for temperature and pressure $\left(0^{\circ} \mathrm{C}, 100 \mathrm{kPa}\right)$. Four ports were located along the digester length to access different zones: sludge bed (P3: $0.07 \mathrm{~m})$, immediately below filter zone (P2: $0.31 \mathrm{~m})$, in the middle of the filter zone (P1: $0.43 \mathrm{~m})$ and in the liquid top layer (P0: $0.56 \mathrm{~m}$ ).

\subsection{Inoculum and substrates}

The hybrid was inoculated with biological solids (suspended biomass) obtained from an anaerobic treatment plant treating piggery effluent, in Alcobertas (Rio Maior, Portugal). The piggery effluent was provided by a pig fattening installation 


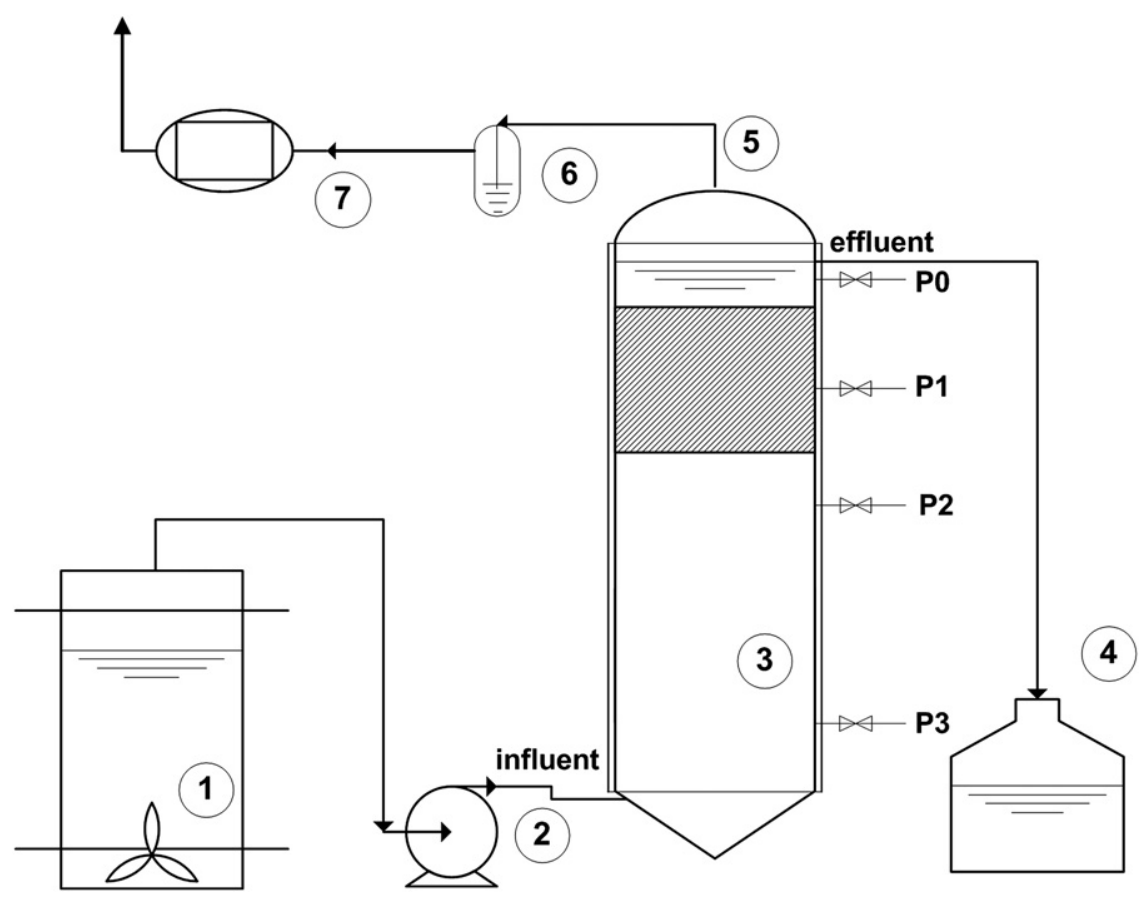

Fig. 1 - Experimental set of the hybrid digester: (1) feeding tank; (2) peristaltic pump; (3) hybrid digester; (4) treated effluent; (5) biogas exit; (6) liquid trap; and (7) gas counter. Sampling zones: P0 - 0.56 m, P1 - 0.43 m, P2 - 0.31 m and P3 - 0.07 m.

from the same geographic zone, and it was used as a complementary substrate in the feed mixture, as described elsewhere [1]. OME came from a three-phase continuous olive oil extraction process in Rio Maior, Portugal. This effluent was generated in the olive oil campaign of 2007/2008 and then it was stored in the olive mill underground tank. The effluents and the sludge were collected in May 2008 when the reactor operation started. Both effluents were characterized at the time of arrival at the laboratory (Table 2) and then stored at $4{ }^{\circ} \mathrm{C}$ until use.

\subsection{Operation mode}

The start-up of the hybrid reactor was carried out with diluted piggery effluent. Then it was closed and remained during 8 days until a volume fraction of $75 \%$ of $\mathrm{CH}_{4}$ in the biogas content was attained. The reactor operation conditions are summarized in Table 3. On day 8 , the reactor started to be fed with an OME volume fraction of $8 \%$ in the feed mixture. The volume fraction of raw OME was gradually increased in the feed mixture from $8 \%$ to $83 \%$ under a HRT (hydraulic retention time) of about 6 days. Piggery effluent was used to add up to

\section{Table 2 - Effluents characterization.}

\begin{tabular}{|c|c|c|}
\hline Parameter & OME & Piggery Effluent \\
\hline $\mathrm{pH}$ & 4.6 & 7.2 \\
\hline Total COD $\left(\mathrm{kg} \mathrm{m}^{-3}\right)$ & 48.6 & 17.7 \\
\hline Soluble COD $\left(\mathrm{kg} \mathrm{m}^{-3}\right)$ & 44.2 & 7.9 \\
\hline $\begin{array}{l}\text { Volatile fatty acids ( } \mathrm{kg} \mathrm{m}^{-3} \text { as } \\
\text { acetic acid) }\end{array}$ & 6.6 & 1.83 \\
\hline $\mathrm{TP}\left(\mathrm{kg} \mathrm{m}^{-3}\right.$ as caffeic acid) & 2.61 & 0.38 \\
\hline Color (absorbance at $390 \mathrm{~nm}$ ) & 19.5 & 2.28 \\
\hline
\end{tabular}

the total volume of the mixture. During all the operation time, no nutrients were added, no chemical correction of $\mathrm{pH}$ and no dilution with tap water were performed. The digester was operated for about 300 days, with the exception of 2 months of interruption between Periods VI and VII. The operation was restarted by feeding the reactor during two days only with piggery effluent and then using an OME volume fraction of $69 \%$ in the feed mixture. The hybrid profile was characterized by collecting samples from the different zones of the reactor at the end of Periods II, IV, and VII. The organic loading rate (OLR) applied was based on the COD content. The COD removal $\left(C O D_{R}\right)$ was determined according to: $\quad C_{R}=\left(C O D_{\text {influent }}-C O D_{\text {effluent }}\right) / C O D_{\text {influent }} \times 100$. The methane yields were expressed as the ratio of the methane produced and the COD removed.

\begin{tabular}{|c|c|c|c|c|}
\hline Period & $\begin{array}{l}\text { OME volume } \\
\text { fraction (\%) }\end{array}$ & $\begin{array}{l}\text { Time } \\
\text { (d) }\end{array}$ & $\begin{array}{l}\text { HRT } \\
\text { (d) }\end{array}$ & $\begin{array}{c}\text { OLR } \\
\left(\mathrm{kg} \mathrm{m}^{-3} \mathrm{~d}^{-1}\right)\end{array}$ \\
\hline I & 8 & $9-46$ & 5.9 & 3.4 \\
\hline II & 12 & $47-83$ & 6.1 & 3.3 \\
\hline III & 18 & 84-109 & 6.5 & 8.0 \\
\hline \multirow[t]{2}{*}{ IV } & 27 & $110-124$ & 5.7 & 3.6 \\
\hline & & $125-137$ & 5.9 & 3.6 \\
\hline V & 41 & $138-166$ & 6.0 & 5.2 \\
\hline VI & 53 & $167-201$ & 5.9 & 6.7 \\
\hline \multicolumn{5}{|c|}{ Interruption (2 months) } \\
\hline VII & 69 & $209-264$ & 5.6 & 6.2 \\
\hline VIII & 83 & $265-297$ & 5.7 & 7.1 \\
\hline
\end{tabular}

OME - olive mill effluent; OLR - organic loading rate of COD; and HRT - hydraulic retention time. 


\subsection{Analytical and chromatograph methods}

Total and soluble chemical oxygen demands (COD) were evaluated using Spectroquant ${ }^{\circledR}$ test kits (Merck). Total and volatile solids (TS and VS) and alkalinity were determined according to Standard Methods [22]. Total phenols (TP) were assessed by a modified Folin-Ciocalteau method [23]. Color was determined by measuring the absorbance at $390 \mathrm{~nm}$. Volatile fatty acids were analyzed in a gas chromatograph (Hewlett Packard ${ }^{\mathrm{TM}}$, 5890) equipped with a flame ionization detector and a $2 \mathrm{~m} \times 0.002 \mathrm{~m}$ Carbopack ${ }^{\mathrm{TM}} \mathrm{B}-\mathrm{DA} / 4 \%$ Carbowax ${ }^{\circledR}$ $20 \mathrm{M}(80-120 \mathrm{mesh})$ column. Nitrogen was used as the carrier gas $\left(0.03 \mathrm{~L} \mathrm{~min}^{-1}\right)$. The temperatures of the column, injector and detector were $170^{\circ} \mathrm{C}, 175^{\circ} \mathrm{C}$ and $250^{\circ} \mathrm{C}$, respectively. Gases were separated in a 1/8" $\times 3$ m Porapak ${ }^{\circledR}$ column (80-100 mesh) and determined with a thermal conductivity detector in a Varian 3800 chromatograph with column, injector and detector temperatures at $50^{\circ} \mathrm{C}, 60^{\circ} \mathrm{C}$ and $100^{\circ} \mathrm{C}$, respectively.

\section{Results and discussion}

\subsection{Reactor performance: biogas production and COD conversion}

The reactor was operated at an OLR between $3.3 \mathrm{~kg} \mathrm{~m}^{-3} \mathrm{~d}^{-1}$ and $8.0 \mathrm{~kg} \mathrm{~m}^{-3} \mathrm{~d}^{-1}$, for 300 days (Table 3). Fig. 2 and Table 4 present the reactor performance results in terms of biogas production, methane content and COD conversion. A good biogas quality was detected throughout the experiment. The methane content in biogas decreased from a volume fraction between $73 \%$ and $79 \%$ (Period I) to 59\% and 66\% (Period VIII) with the increase of OLR. Conversely, a gradual enhancement of biogas productivities was observed. A biogas production of $3.16 \mathrm{~m}^{3} \mathrm{~m}^{-3} \mathrm{~d}^{-1}$ was achieved at an OLR of $7.1 \mathrm{~kg} \mathrm{~m}^{-3} \mathrm{~d}^{-1}$ (Period VIII), when the highest fraction of OME was included in the influent (the volume fraction was $83 \%$ ).

The increase of organic loading rate was provided by the increasing of OME fraction in the feed mixture, with the exception of Period III. At this stage, an accidental overloading occurred that was attributed to PE load. The feed mixture was prepared with an OME volume fraction of $18 \%$ and a piggery effluent volume fraction of $82 \%$. The PE that was used to prepare the feed in this period was more concentrated in terms of solids than previous streams which resulted in an influent total COD of $51.6 \mathrm{~kg} \mathrm{~m}^{-3}$ and total solids of $53.1 \mathrm{~kg} \mathrm{~m}^{-3}$. A sudden increase in biogas production was observed attaining a maximum of $2.41 \mathrm{~m}^{3} \mathrm{~m}^{-3} \mathrm{~d}^{-1}$. However, the methane yield reduction to $0.290 \mathrm{~m}^{3} \mathrm{~kg}^{-1}$ suggested that substrate was being accumulated inside the reactor. At the end of Period III, the biologic solids blanket went upwards and penetrated the fixed bed section. Consequently, a relatively poor effluent quality was obtained with relatively low $C O D$ removal $\left(\mathrm{COD}_{\mathrm{R}}=58 \%\right)$ and with high solids content. Some biomass was lost but it did not cause the failure of the unit. The ability of resisting to this type of accident was tested by introducing a new influent with a higher OME portion in the feed mixture (volume fraction of $27 \%$ ). At the first part of Period IV, the reactor performance was affected by the incident. Total COD removal was low $\left(\mathrm{COD}_{\mathrm{R}}=40 \%\right)$ but $\mathrm{CH}_{4}$ production was higher than the theoretical, suggesting that the accumulated substrate from the previous period was degraded. At the final of Period IV (day $125-137) \mathrm{COD}$ removal increased $\left(\mathrm{COD}_{\mathrm{R}}=60 \%\right)$ and biogas production decreased to values closer to those expected, indicating that the hybrid digester was able to recover after an accidental overloading disturbance.

The operation interruption between Periods VI and VII did not cause any problem. Biogas production was rapidly enhanced achieving values of $2.4 \mathrm{~m}^{3} \mathrm{~m}^{-3} \mathrm{~d}^{-1}$. Total and soluble COD removal values were high and stable (total $\mathrm{COD}_{\mathrm{R}}=70-79 \%$ and soluble $\mathrm{COD}_{\mathrm{R}}=75-80 \%$ ) from Period $\mathrm{V}$ to VIII. The results show an improvement of reactor performance suggesting that biomass was gradually acclimated to olive mill effluent and to its toxic/recalcitrant compounds. The degradation of olive mill effluent (volume fraction of 83\%; COD concentration fraction of about $94 \%$ ) occurred without any inhibition, attaining values around the theoretical $\left(0.35 \mathrm{~m}^{3} \mathrm{~kg}^{-1}\right)$. Biomass acclimation to OME compounds has been referred as an important issue to improve wastewater biodegradation [24]. In this work, the progressively increasing amount of OME amended with piggery effluent stimulated biomass acclimation and, consequently, higher bioenergy recovery was achieved.

\section{2. $p H$, alkalinity and VFAs}

The hybrid reactor worked under pHs extremely inhibitors to the methanogenic bacteria during the two final operational

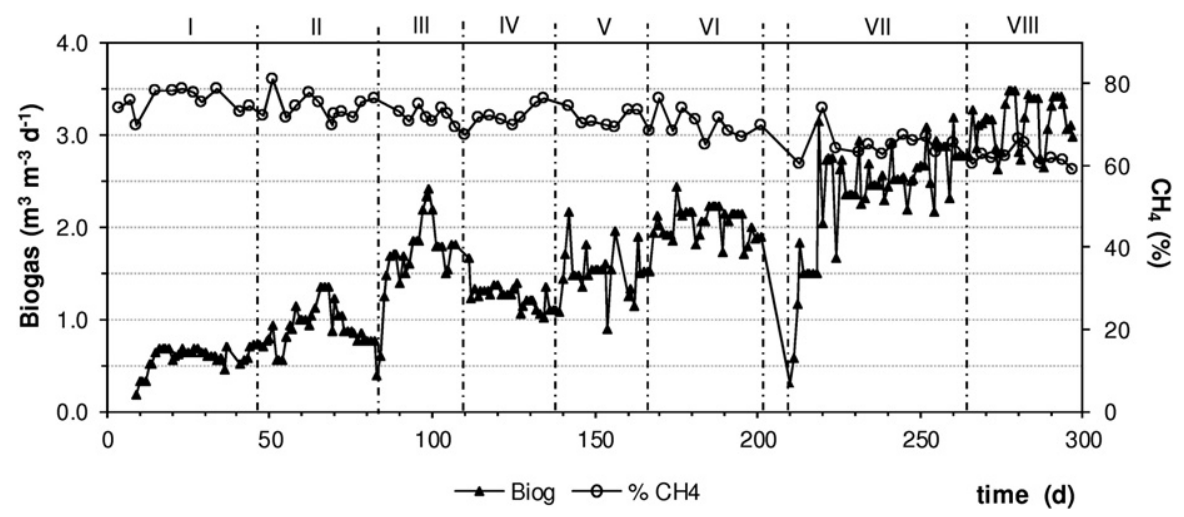

Fig. 2 - Reactor performance. Biogas production and methane content. 
Table 4 - Hybrid performance data: summary results (mean values \pm standard deviation; number of data in brackets).

\begin{tabular}{|c|c|c|c|c|c|c|c|c|c|c|}
\hline \multirow[t]{2}{*}{ Period } & \multirow{2}{*}{$\begin{array}{l}\text { OME volume } \\
\text { fraction (\%) }\end{array}$} & \multicolumn{3}{|c|}{ Total COD } & \multicolumn{3}{|c|}{ Soluble COD } & \multirow{2}{*}{$\begin{array}{c}\text { Biogas } \\
\left(\mathrm{m}^{3} \mathrm{~m}^{-3} \mathrm{~d}^{-1}\right)\end{array}$} & \multirow{2}{*}{$\begin{array}{l}\mathrm{CH}_{4} \\
(\%)\end{array}$} & \multirow{2}{*}{$\begin{array}{l}\mathrm{CH}_{4} \text { yield } \\
\left(\mathrm{m}^{3} \mathrm{~kg}^{-1}\right)\end{array}$} \\
\hline & & $\begin{array}{c}\text { Inf. } \\
\left(\mathrm{kg} \mathrm{m}^{-3}\right)\end{array}$ & $\begin{array}{c}\text { Eff. } \\
\left(\mathrm{kg} \mathrm{m}^{-3}\right)\end{array}$ & $\begin{array}{c}\mathrm{COD}_{\mathrm{R}} \\
(\%)\end{array}$ & $\begin{array}{c}\text { Inf. } \\
\left(\mathrm{kg} \mathrm{m}^{-3}\right)\end{array}$ & $\begin{array}{c}\text { Eff. } \\
\left(\mathrm{kg} \mathrm{m}^{-3}\right)\end{array}$ & $\begin{array}{c}\mathrm{COD}_{\mathrm{R}} \\
(\%)\end{array}$ & & & \\
\hline II & 12 & $20.0 \pm 1.9_{(3)}$ & $8.2 \pm 0.7_{(4)}$ & 58.8 & $10.1 \pm 1.0_{(4)}$ & $3.5 \pm 0.3_{(4)}$ & 65.4 & $0.91 \pm 0.21_{(36)}$ & $74.3 \pm 3.1_{(12)}$ & 0.352 \\
\hline III & 18 & $51.6 \pm 7.6_{(4)}$ & $22.0 \pm 11.6_{(4)}$ & 57.4 & $12.1 \pm 1.7_{(4)}$ & $5.1 \pm 0.6_{(4)}$ & 57.8 & $1.85 \pm 0.27_{(17)}$ & $71.6 \pm 2.4_{(8)}$ & 0.290 \\
\hline \multirow[t]{2}{*}{ IV } & 27 & $20.9 \pm 0.3_{(2)}$ & $12.5 \pm 3.7_{(2)}$ & 40.3 & $17.4 \pm 0.0_{(2)}$ & $4.3 \pm 0.3_{(2)}$ & 75.2 & $1.32 \pm 0.11_{(14)}$ & $71.7 \pm 0.4_{(4)}$ & 0.644 \\
\hline & & $21.3 \pm 0.3_{(2)}$ & $8.5 \pm 0.3_{(2)}$ & 60.1 & $17.5 \pm 0.0_{(2)}$ & $4.9 \pm 0.2_{(2)}$ & 72.0 & $1.17 \pm 0.12_{(13)}$ & $73.3 \pm 3.1_{(4)}$ & 0.391 \\
\hline V & 41 & $30.9 \pm 1.1_{(3)}$ & $8.5 \pm 0.7_{(5)}$ & 72.6 & $22.8 \pm 3.4_{(5)}$ & $5.4 \pm 0.3_{(5)}$ & 76.3 & $1.49 \pm 0.25_{(19)}$ & $71.3 \pm 2.2_{(7)}$ & 0.284 \\
\hline VI & 53 & $39.4 \pm 1.7_{(3)}$ & $10.1 \pm 0.9_{(4)}$ & 74.5 & $27.3 \pm 1.6_{(3)}$ & $6.7 \pm 0.5_{(4)}$ & 75.6 & $2.05 \pm 0.18_{(27)}$ & $70.2 \pm 3.5_{(10)}$ & 0.288 \\
\hline VII & 69 & $35.0 \pm 0.9_{(4)}$ & $10.5 \pm 1.3_{(7)}$ & 69.9 & $32.4 \pm 0.8_{(3)}$ & $8.0 \pm 1.2_{(7)}$ & 75.4 & $2.36 \pm 0.29(54)$ & $65.7 \pm 3.1_{(12)}$ & 0.356 \\
\hline VIII & 83 & $40.7 \pm 3.5_{(3)}$ & $8.7 \pm 0.7_{(4)}$ & 78.6 & $37.2 \pm 0.8_{(3)}$ & $7.4 \pm 0.1_{(3)}$ & 80.0 & $3.16 \pm 0.29_{(25)}$ & $62.1 \pm 2.3_{(10)}$ & 0.349 \\
\hline
\end{tabular}

periods (Periods VII and VIII). The influent $\mathrm{pH}$ decrease to values of about 4.7 (Fig. 3), throughout the experiment, is attributed to the OME fraction increase in the digester feed. On the other hand, the $\mathrm{pH}$ levels of reactor effluents were about 7.5. Additionally, the $\mathrm{pH}$ measured inside the reactor (sampling zones) was neutral. The results revealed a high buffering capacity of the unit. The digester capacity of receiving a low $\mathrm{pH}$ feed was also observed by Marques [18] in an anaerobic filter, after an adaptation process. The AF reactor, filled with packing media, was probably able to define different $\mathrm{pH}$ sections and as well as different microbial communities zones [25]. This type of procedure, feeding with an acid substrate ( $\mathrm{pH}$ of 4.7), had never been performed in a hybrid reactor treating OME. In all the reported procedures in the literature, OME is firstly amended to neutral pHs before its digestion [12], which carries higher costs for the plant operation.

VFAs concentrations are presented in Fig. 3. Effluent VFAs were up to $0.26 \mathrm{~kg} \mathrm{~m}^{-3}$ as acetic acid throughout the operation, except in Period IV where an increase of VFAs levels was noticed. At this point, butyric acid was detected and high concentrations of propionic acid were obtained (the mass fraction of propionic was $45 \%$ ). The presence of butyric and propionic acids is indicative of process instability/stress, which in this case may be related to the accidental overload through the previous operational period. During influent $\mathrm{pH}$ critical periods (VII and VIII), the effluents VFAs concentrations were in the range of $0.09 \mathrm{~kg} \mathrm{~m}^{-3}-0.11 \mathrm{~kg} \mathrm{~m}^{-3}$, in which acetic acid was the predominant VFA, present at mass fractions of $79 \%$ and $83 \%$ for Periods VII and VIII, respectively. Influent VFAs were very high $\left(7.5 \mathrm{~kg} \mathrm{~m}^{-3}-8.4 \mathrm{~kg} \mathrm{~m}^{-3}\right.$ as acetic acid) probably due to the OME storage. According to Tsonis and Grigoropoulos [26], this type of effluent has the ability for fermenting while in storage, which gives rise to substantial changes in the composition.

Table 5 presents the alkalinity during critical periods in terms of $\mathrm{pH}$ (VII and VIII). The influent total alkalinity was below the range for a suitable anaerobic digestion (optimal range from $2.5 \mathrm{~kg} \mathrm{~m}^{-3}$ to $3.0 \mathrm{~kg} \mathrm{~m}^{-3}$ as $\mathrm{CaCO}_{3}$ [27]). However, an effluent was obtained with a total alkalinity of 5.2 and $4.6 \mathrm{~kg} \mathrm{~m}^{-3}$ as $\mathrm{CaCO}_{3}$ and a partial alkalinity of 4.2 and $3.5 \mathrm{~kg} \mathrm{~m}^{-3}$ as $\mathrm{CaCO}_{3}$, for Periods VII and VIII, respectively. This fact suggests that alkalinity levels inside the reactor were maintained at favorable concentrations and consequently the $\mathrm{pH}$ was close to neutrality. It was demonstrated that the reactor was capable of digest an influent with a $\mathrm{pH}$ of 4.7, revealing high buffering capacity.

\subsection{Total phenols and color}

Total phenols from Periods IV to VIII are presented in Fig. 4. The presence of phenolic compounds in the influent is mainly ascribed to the OME fraction. In consonance, a gradual increase of total phenols was observed in the influent from values of $0.87 \mathrm{~kg} \mathrm{~m}^{-3}$ (Period IV) to $2.31 \mathrm{~kg} \mathrm{~m}^{-3}$ (Period VIII). The removed phenolic fraction was constant between $51 \%$ and $61 \%$.

These results are in accordance to Azbar et al. [12] that used a hybrid digester to treat OME at an OLR of $6.85 \mathrm{~kg} \mathrm{~m}^{-3} \mathrm{~d}^{-1}$ and a HRT of 7.5 days. They reported that the removed phenolic fraction was $52 \%$ of the total phenols when

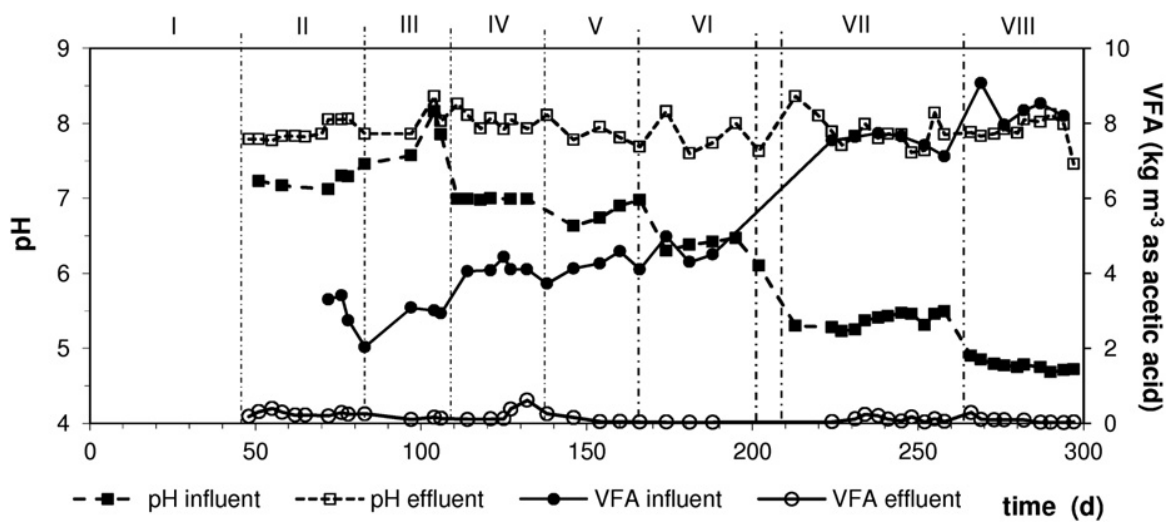

Fig. 3 - pH and VFA of reactor influent and effluent. 
Table 5 - Flows alkalinity (average \pm standard deviation; number of data in brackets).

\begin{tabular}{llll}
$\begin{array}{l}\text { Period/OME } \\
\text { volume fraction }\end{array}$ & & VII/69\% & VIII/83\% \\
\hline Partial alkalinity & Influent & $0.0 \pm 0.0_{(2)}$ & $0.0 \pm 0.0_{(2)}$ \\
$\left(\mathrm{kg} \mathrm{m}^{-3}\right.$ as $\left.\mathrm{CaCO}_{3}\right)$ & Effluent & $4.2 \pm 0.1_{(5)}$ & $3.5 \pm 0.3_{(3)}$ \\
Total alkalinity & Influent & $1.7 \pm 0.0_{(2)}$ & $2.0 \pm 0.0_{(2)}$ \\
$\left(\mathrm{kg} \mathrm{m}^{-3}\right.$ as $\left.\mathrm{CaCO}_{3}\right)$ & Effluent & $5.2 \pm 0.1_{(5)}$ & $4.6 \pm 0.2_{(3)}$ \\
\hline
\end{tabular}

the influent contained $1.56 \mathrm{~kg} \mathrm{~m}^{-3}$ of total phenols. Marques [1] operated an anaerobic filter with an OLR between $3.5 \mathrm{~kg} \mathrm{~m}^{-3} \mathrm{~d}^{-1}$ and $6.6 \mathrm{~kg} \mathrm{~m}^{-3} \mathrm{~d}^{-1}$ at HRT of around 6 days and reported that the removed phenolic fraction was $63 \%$ (average) for an influent with $1.26 \mathrm{~kg} \mathrm{~m}^{-3}$ of total phenols.

In this work, the three-fold increase of phenolic compounds in the influent did not promote a decrease in the reactor's removal capacity. The results suggest that the concentration of phenols in the influent does not have a decisive effect on the phenolic compounds removal. This fact seems to be more related to the type of phenols fraction that is not removed by anaerobiosis than to the concentration itself.

The hybrid profile was performed at the final (steady state conditions) of Periods II, IV and VII, regarding the phenolic compounds removal (Fig. 5). In the Period II, the phenolic compounds accumulated in the first sector of the column $(0.07 \mathrm{~m})$, its removal being mostly observed in the remaining section under the packing sector. Tannin polymers can be effectively adsorbed or precipitated with proteins which lead to their toxic effect [4]. A slight accumulation was observed in the filter zone as well. At higher OLR (Periods IV and VII) most of the phenolic compounds removal was mainly taking place at the hybrid base, suggesting that biomass in the sludge bed was effective and an acclimation of the microbial consortium occurred along the experimental period. In our work, the removed color fraction was up to $30 \%$ at the highest concentrations, and sometimes the color intensity increased after the digestion process. Field and Lettinga [5] studied the effect of oxidative coloration on the methanogenic toxicity and biodegradability of a synthetic phenolic solution. They found that colored compounds were not biodegradable and their presence did not affect the biodegradability of colorless compounds.
Instead of removing toxic/inhibitory phenolic compounds by using a pretreatment, a biomass acclimation process improves bioenergy recovery from OME. The remaining nonbiodegradable fraction that is not toxic to methanogenic bacteria can be useful for agricultural application or can be degraded by means of a post-treatment when it has to be discharged into the sewer systems.

\subsection{Feeding strategy application and reactor type}

In this work it was demonstrated that piggery effluent was effective as OME complementary substrate since biomass acclimation to higher OME proportions was accomplished under low pH. Concerning a real application, the needless of chemicals and nutrients provides a cost reduction of the OME valorization process.

Piggery effluent is an interesting alternative to amend OME stream and to enable its biodegradation. The energetic potential of some streams as piggery effluent is not enough to sustain a biogas plant. An alternative feeding strategy for OME disposal in a piggery effluent anaerobic treatment plant is proposed based on the results of this work. Nowadays, OME is temporarily stored in tanks and then discharged into sewers systems and rivers. Considering that a biogas plant treating piggery effluent is running during all the year, increasing quantities of OME can be injected to the influent stream. The feeding strategy allows adapting biomass and preventing operation problems as demonstrated in this experimental work. Throughout olive oil campaign (3-4 months) the feeding could be prepared by using essentially OME. Moreover, the feed mixture preparation is user-friendly since it can be done easily by volumetric measure without any addition of water or chemicals.

The typical UASB operation problems caused by effluents with high lipid content (foam formation and washout) were overcome by using a hybrid digester. The packing material at the top of the hybrid acted as a safe zone preventing the biomass washout and providing a stable operation. Moreover, the hybrid was effective regarding the adverse effects of an accidental overload (Period III of reactor operation). The maintenance of a sufficient amount of biomass inside the unit allowed avoiding the process failure. The interest in evaluating the use of hybrid variant is not only based on the fact

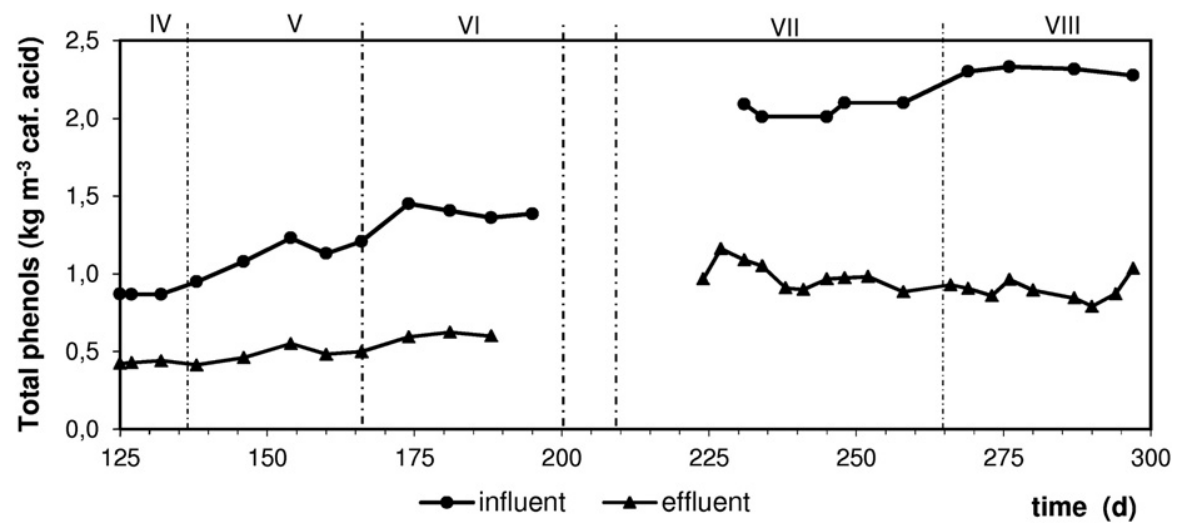

Fig. 4 - Total phenols in the influent and effluent from IV to VIII periods. 


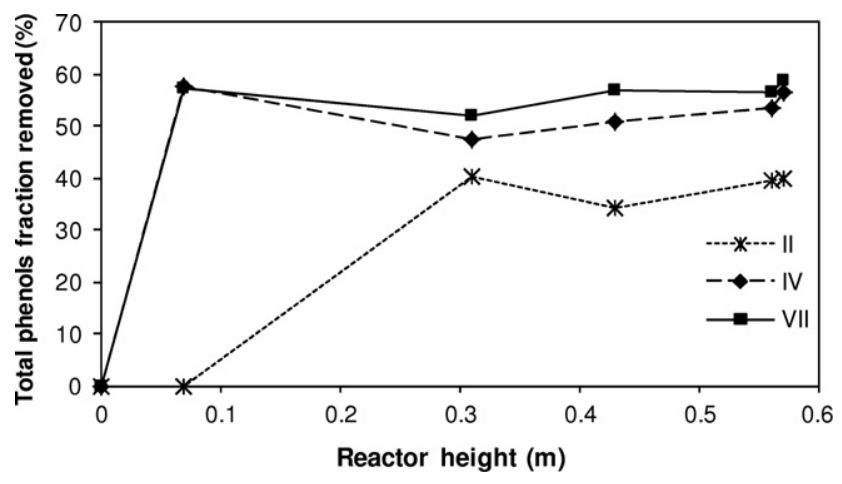

Fig. 5 - Hybrid profile: total phenols removal at the final of periods II, IV and VII.

that its implementation may avoid the operational troubles related to the progenitors units, but also on an economic perspective since the packing material may be reduced to $1 / 3$ of the digester height.

\section{Conclusions}

The hybrid digester, equipped with a packed bed of only $1 / 3$ of its height, is a feasible alternative to maximize the bioenergy recovery from OME. It prevents the excessive loss of biomass and recovers easily over an accidental overload. It was demonstrated that microbial communities can be adapted to OME by using a feeding strategy based on effluents complementarity, avoiding dilution with water and chemicals.

It was concluded that only a phenolic fraction of $50-60 \%$ can be anaerobically degraded. Consequently, a posttreatment is necessary in order to remove coloration mainly caused by remaining recalcitrant phenolic compounds.

Regarding a real application, the needless of chemicals, nutrients, and water to correct the OME and the absence of a hybrid settler device, associated with a packed bed reduction to $1 / 3$ of its height, are factors that constitute a significant reduction in costs of implementing a plant.

\section{Acknowledgements}

The authors acknowledge the financial support of Fundação para a Ciência e a Tecnologia (FCT/MCTES) and Fundo Social Europeu (FSE), through the project PTDC/ENR/69755/2006 and also through the grant awarded to Marta Gonçalves SFRH/BD/ $40746 / 2007$.

\section{R E F E R E N C E S}

[1] Marques IP. Anaerobic digestion treatment of olive mill wastewater for effluent re-use in irrigation. Desalination 2001;137:233-9.

[2] Beccari M, Bonemazzi F, Majone M, Riccardi C. Interaction between acidogenesis and methanogenesis in the anaerobic treatment of olive oil mill effluents. Water Res 1996;30(1): 183-9.
[3] Beccari M, Carucci G, Majone M, Torrisi L. Role of lipids and phenolic compounds in the anaerobic treatment of olive oil mill effluents. Environ Technol 1999;20(1): 105-10.

[4] Field JA, Lettinga G. The methanogenic toxicity and anaerobic degradability of a hydrolysable tannin. Water Res 1987;21(3):367-74.

[5] Field JA, Lettinga G. The effect of oxidative coloration on the methanogenic toxicity and anaerobic biodegradability of phenols. Biol Waster 1989;29(3):161-79.

[6] Dhouib A, Aloui F, Hamad N, Sayadi S. Pilot-plant treatment of olive mill wastewaters by phanerochaetechrysosporium coupled to anaerobic digestion and ultrafiltration. Process Biochem 2006;41(1):159-67.

[7] Sabbah I, Marsook T, Basheer S. The effect of pretreatment on anaerobic activity of olive mill wastewater using batch and continuous systems. Process Biochem 2004;39(12): 1947-51.

[8] Zouari N, Ellouz R. Toxic effect of coloured olive compounds on the anaerobic digestion of olive oil mill effluent in UASBlike reactors. J Chem Tech Biotechnol 1996;66(4):414-20.

[9] Boari G, Brunetti A, Passino R, Rozzi A. Anaerobic digestion of olive oil mill wastewaters. Agr Wastes 1984;10(3):161-75.

[10] Gannoun H, Othman NB, Bouallagui H, Moktar H. Mesophilic and thermophilic anaerobic co-digestion of olive mill wastewaters and abattoir wastewaters in an upflow anaerobic filter. Ind Eng Chem Res 2007;46(21):6737-43.

[11] Borja R, Alba J, Banks C. Anaerobic digestion of wash waters derived from the purification of virgin olive oil using a hybrid reactor combining a filter and a sludge blanket. Process Biochem 1996;31(3):219-24.

[12] Azbar N, Tutuk F, Kesin T. Biodegradation performance of an anaerobic hybrid reactor treating olive mil effluent under various organic loading rates. Int Biodeterior Biodegradation 2009;63(6):690-8.

[13] Azbar N, Keskin T, Yuruyen A. Enhancement of biogas production from olive mill effluent (OME) by co-digestion. Biomass Bioenergy 2008;32(12):1195-201.

[14] Fountoulakis M, Drakopoulou S, Terzakis S, Georgaki E, Manios T. Potential for methane production from typical Mediterranean agro-industrial by-products. Biomass Bioenergy 2008;32(2):155-61.

[15] Dareioti M, Dokianakis S, Stamatelatou K, Zafiri C, Kornaros M. Exploitation of olive mill wastewater and liquid cow manure for biogas production. Waste Manag 2010;30(10): 1841-8.

[16] Marques IP, Teixeira A, Rodrigues L, Martins Dias S, Novais JM. Anaerobic co-treatment of olive mill and piggery effluents. Environ Technol 1997;18(3):265-74.

[17] Ubay G, Ozturk I. Anaerobic treatment of olive mill effluents. Water Sci Technol 1997;36(2-3):287-94.

[18] Marques IP. Valorisation of polluters resources by anaerobic digestion. Olive mill wastewater and piggery effluent. PhD thesis, Technical University of Lisbon; 2000.

[19] Kapellakis IE, Tsagarakis KP, Crowther JC. Olive oil history, production and by-product management. Rev Environ Sci Biot 2008;7(1):1-26.

[20] El-Gohary F, Tawfik A, Badawy M, El-Khateeb MA. Potentials of anaerobic treatment for catalytically oxidized olive mill wastewater (OMW). Bioresource Technol 2009;100(7): 2147-54.

[21] Ayati B, Ganjidoust H. Comparing the efficiency of UAFF and UASB with hybrid reactor in treating wood fiber wastewater. Iran J Environ Healt 2006;3(1):39-44.

[22] American Public Health Association, American Water Works Association, Water Environment Federation. Standard methods for the examination of water and wastewater. 20th ed. Washington, DC: The Associations and Federation; 1998. 
[23] Singleton VL, Rossi Jr JA. Colorimetryof total phenolics with phosphomolybdic-phosphotungstic acid reagents. Am J Enol Viticult 1965;16(3):144-58.

[24] Gonçalves MR, Costa JC, Marques IP, Alves MM. Inoculum acclimation to oleate promotes the conversion of olive mill wastewater to methane. Energy 2011;36(4):2138-41.

[25] Eusébio A, Tacão M, Baeta-Hall L, Freitas P, Almeida-Vara E, Marques IP. TGGE - monitoring of the microbial community along the olive mill wastewaters anaerobic treatment. In: Cebio, editor. Bioenergy: challenges and opportunities, April 6th to 9th 2008, Guimarães, Portugal. Guimarães, Portugal: Universidade do Minho; 2008. p. 73-8.

[26] Tsonis S, Grigoropoulos G. High-rate anaerobic treatment of olive mill wastewater. In: Hall ER, Hosson PN, editors. Fifth international symposium on anaerobic digestion, May 1988, Bologna, Italy. Oxford, UK: Pergamon Press; 1988. p. $115-24$.

[27] Björnsson L, Murto M, Mattiasson B. Evaluation of parameters for monitoring an anaerobic co-digestion. Appl Microbiol Biotechnol 2000;54(6):844-9. 